\title{
Bioethanol production from cotton stalks or corn stover? A comparative study of their sustainability performance
}

\author{
Costas P. Pappis ${ }^{1, *}$, Evangelos C. Petrou ${ }^{1}$ \\ ${ }^{1}$ University of Piraeus, Department of Industrial Management and Technology, 80 Karaoli and Dimitriou Street, \\ 18534, Piraeus, Greece \\ *Corresponding author. Tel: +30 2104142150,Fax: +30 2104142342,E-mail:pappis@unipi.gr, \\ epetrou@unipi.gr
}

\begin{abstract}
The production of second generation biofuels (ones produced from lignocellulosic materials) has not yet been developed in a full commercial scale. However, a considerable number of pilot and demonstration plants have been announced or set up in recent years, with research activities taking place mainly in North America, Europe and a few other countries (e.g. Brazil, China, India etc). At the same time their environmental and economic performance are under examination. These performance issues are very sensitive on a variety of parameters such as feedstock material, production technology, logistics involved etc. In this study the sustainability performance of two alternative bioethanol's production systems, namely, one using cotton stalks and a second one using corn stover feedstock, are examined and compared using the Analytic Hierarchy Process method. Life Cycle Impact Assessment is used in order to evaluate each alternative's environmental performance. For this purpose, a modern powerful and state of the art software (SimaPro) is used. The systems' economic performance is based on cost/ benefit calculations.
\end{abstract}

Keywords: Bioethanol, Analytical Hierarchy Process, Life Cycle Impact Assessment

\section{Introduction}

Lignocellulosic materials, particularly agricultural residues, seem to be a very attractive source for bio-fuels' production (second generation biofuels) as indicated in recent literature [1],[2],[3]. The reasons for this are, first, they have a big potential, second, they have no adverse effect on food production, and, third, they have the least negative impacts (economic, environmental and social) to human systems compared to energy plant cultivations. Although the production of such biofuels has not yet been developed in a full commercial scale, several pilot and demonstration plants have been announced or set up. Relevant research activities, including performance issues such as environmental and economic ones, are taking place, mainly in North America, Europe and a few other countries [4],[5]. In general, the performance of such materials when used for the production and supply of biofuels depends on a variety of parameters such as kind of feedstock material, production technology, logistics involved etc. The evaluation of such performance is not straightforward, particularly in cases where multiple unrelated objectives or attributes have to be taken into account in the decision making process. In such cases, Operational Research methodologies have to be employed in order to arrive at safe conclusions. In this study the sustainability performance of two candidate alternative bioethanol's production systems, namely, one using cotton stalks and a second one using corn stover feedstock, are examined and compared using the Analytic Hierarchy Process method. Sustainability is meant to be composed of two criteria, namely the economic and the environmental ones, which have been taken into account for the final evaluation. Life Cycle Impact Assessment and, more specifically, the Eco-Indicator 99 method is used in order to evaluate each alternative's environmental performance. For this purpose, a modern powerful and state of the art software (SimaPro) is employed, while cost/ benefit calculations are used for the evaluation of the systems' economic performance. The result in the present case study is that corn stover is always preferable as a feedstock material. 


\section{Methodology}

The methodology employed in this case study is as follows:

The sustainability performance of each bioethanol production system is expressed as a performance index combining the environmental and economic criteria and is calculated using the Analytic Hierarchy Process [6]. Cost/ benefit calculations are used for the evaluation of the systems' economic performance, while the environmental performance is evaluated by the Eco-Indicator 99 (EI 99) method. The combined performance index is then used for the selection of the best scenario from a sustainability perspective. A popular and state of the art software (SimaPro-Version 7.1) is used to determine the environmental performance of each scenario. SimaPro is a professional tool for collecting, analyzing and monitoring the environmental performance of products and services, following the ISO 14040 series recommendations. Amongst the Life Cycle Impact Assessment methods used by this software EI 99 is selected, since it is used extensively in similar evaluations and, in addition, it includes the land use impact category, which is important in agricultural production systems (as in the case of cotton and corn cultivation). The 2002 National Renewable Energy Laboratory's (NREL) report, referring to the design of the ethanol production system based on corn stover biomass, was used as a standard for the description of the production systems under evaluation [7]. Also data concerning the unit processes describing each production system were gathered by field research in Greece. Where no data were available proper assumptions were made. The economic performance of each alternative was measured in terms of total supply chain cost, in particular operational cost from field to distillery as the other costs are the same for both alternatives. The plant is assumed to be situated in the district of Thessaly since it can provide either the whole needed biomass quantity (in the case of corn stover) or the major part of it (in the cotton stalks case). The selected unit basis is $1 \mathrm{Kg} \mathrm{EtOH} \mathrm{(95 \%} \mathrm{in}$ water) at the distillery.

\section{The alternative systems}

Both alternative systems are evaluated in respect to the "field to distillery" bioethanol production, which includes the following stages: feedstock harvesting from fields; transport and feedstock storage \& handling (size reduction etc); pretreatment and hydrolyzate conditioning process; saccharification and co-fermentation process; product, solids and water recovery stage (distillation, dehydration, evaporation and solid-liquid separation); wastewater treatment; product storage; power co-generation (by-product combustion for steam and electricity generation).

\section{Alternative system A: Ethanol production from corn stover}

The system is fed with corn stover harvested in Greece (Thessaly district). Key figures of the production system are presented in Table 1.

Table 1: Key figures for ethanol production from corn stover

\begin{tabular}{|c|c|c|}
\hline & Value & Note \\
\hline $\begin{array}{l}\text { Feedstock quantity (t corn stover on a } \\
\text { dry basis/yr) }\end{array}$ & 750,000 & \\
\hline Harvested area (ha) & 125,000 & \\
\hline $\begin{array}{llll}\text { Average distance } & \text { for } & \text { feedstock } \\
\text { transportation }(\mathrm{km}) & & \end{array}$ & 70 & $\begin{array}{l}5 \mathrm{~km} \text { by tractor+ rail and } \\
65 \mathrm{Km} \text { by lorry } 28 \mathrm{t}\end{array}$ \\
\hline Capacity (t ethanol/yr) & 213,300 & \\
\hline Power co-generated (Mwh/yr) & 160.000 & $\begin{array}{lcc}2.28 & \mathrm{KWh} / \text { gal } & \mathrm{EtOH} \\
\text { according to NREL report }\end{array}$ \\
\hline
\end{tabular}


The total feedstock quantity needed comes from Thessaly. The industrial process yield in the distillery is $284.4 \mathrm{~g} / \mathrm{Kg}$ of dry feedstock. This value is $80 \%$ of the theoretical yield based on the chemical composition of corn stover as provided by NREL measurements [7] (measurements refer to the US). Corn stover is composed of glucan (37.4\%), xylan $(21.1 \%)$, lignin (18.0\%) arabinan (2.9\%), galactan (2.0\%), mannan (1.6\%), ash (5.2\%), acetate $(2.9 \%)$, protein (3.1\%), extractives (4.7\%) and unknown soluble solids (1.1\%) (composition in \% w/w on a dry basis). Since similar data for Greek corn stover are not available, we assume that their composition, and thus the yield of the industrial process, is identical to those of the US case.

\section{Alternative system B: Ethanol production from cotton stalks}

The system is fed with cotton stalks harvested in Greece (Thessaly and Macedonia districts). Key figures of the system are presented in Table 2.

Table 2: Key figures for ethanol production from cotton stalks

\begin{tabular}{|c|c|c|}
\hline & Value & Note \\
\hline $\begin{array}{l}\text { Feedstock quantity (t cotton stalks on a dry } \\
\text { basis/yr) }\end{array}$ & 750,000 & \\
\hline Harvested area (ha) & 300,000 & \\
\hline $\begin{array}{l}\text { Average distance for feedstock } \\
\text { transportation }(\mathrm{km})\end{array}$ & 226 & $\begin{array}{l}16 \mathrm{~km} \text { by tractor }+ \text { rail and } \\
210 \mathrm{Km} \text { by lorry } 28 \mathrm{t}\end{array}$ \\
\hline Capacity (t ethanol/yr) & 134,025 & \\
\hline By-product electricity (Mwh/yr) & 269,000 & $\begin{array}{l}\text { Proportional to lignin } \\
\text { concentration of feedstock }\end{array}$ \\
\hline
\end{tabular}

$60 \%$ of needed feedstock is assumed to come from Thessaly and the rest from Macedonia. The industrial process yield in the distillery is assumed to be $80 \%$ of the theoretical yield based on cotton stalks chemical composition as in the case of corn stover ethanol production. Since chemical composition data for the Greek cotton stalks are not available, data from the literature were used [8]. Cotton stalks are composed of glucan (31,1\%), xylan (8,3\%), lignin (30.1\%) arabinan (1.3\%), galactan (1.1\%), ash (6.0\%), extractives (9.0\%), and others (13.1\%) (composition in \% w/w on a dry basis). The aforementioned yield is based on the chemical composition mentioned above and is $178.7 \mathrm{~g} / \mathrm{kg}$ of dry feedstock.

\section{Results}

\subsection{Environmental criteria}

The environmental performance of each of the alternatives was assessed using Life Cycle Impacts Analysis (realized by Sima-Pro). The following impact categories are selected as environmental criteria: Carcinogens, Respiratory organics effects, Respiratory inorganics effects, Climate change, Radiation effects, Ozone layer depletion, Ecotoxicity, Acidification / eutrophication, Land use, Minerals and Fossil fuels. No uncertainty evaluation was performed in this study.

\subsubsection{Alternative's A Environmental Performance}

For the evaluation of the environmental impacts, data from the Ecoinvent Report n.17 [9] about the inventory and the emissions, in addition to those of the NREL report [7], and data collected through field research were used. Some indicative emissions, in terms of volume produced per unit, are presented in Table 3. 
Table 3: Indicative emissions from the corn stover ethanol production system

\begin{tabular}{lll}
\hline & Value & Note \\
\hline $\mathrm{CO}_{2}$ biogenic $(\mathrm{Kg} / \mathrm{Kg} \mathrm{EtOH})$ & 2.93 & Emissions to air \\
Heat waste emissions $(\mathrm{MJ} / \mathrm{kg}$ EtOH$)$ & 25.85 & Emissions to air \\
$\mathrm{CO}(\mathrm{Kg} / \mathrm{Kg}$ EtOH) & 0.000497 & Emissions to air \\
Methane biogenic $(\mathrm{Kg} / \mathrm{Kg} \mathrm{EtOH})$ & $3.0 * 10^{-5}$ & Emissions to air \\
Mineral oil $(\mathrm{Kg} / \mathrm{Kg} \mathrm{EtOH})$ & 0.000426 & Disposal \\
\hline
\end{tabular}

The resultant value for EI 99 of alternative A is 0.157. The system's performance per impact category is presented in Table 4. For reasons of comparison, the performance of the system

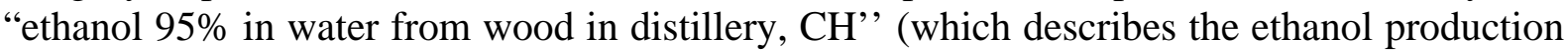
system from residual wood in Switzerland and is included in the Ecoinvent Database [10]), is given in the same Table.

Table 4: Environmental Performance of the production systems under evaluation

\begin{tabular}{|c|c|c|c|}
\hline & $\begin{array}{l}\text { EtOH }^{(*)} \text { from } \\
\text { corn stover }\end{array}$ & $\begin{array}{l}\text { EtOH }^{(*)} \text { from } \\
\text { cotton stalks }\end{array}$ & $\begin{array}{ll}\text { EtOH }^{(*)} & \text { from } \\
\text { wood } & \end{array}$ \\
\hline Carcinogens & 0.00449 & 0.00766 & 0.00252 \\
\hline Respir. Organics effects & $2.89 * 10^{-5}$ & $7.51 * 10^{-5}$ & $1.89 * 10^{-5}$ \\
\hline Respir. Inorganics effects & 0.0266 & 0.0629 & 0.012 \\
\hline Climate change & 0.0122 & 0.0333 & -0.00557 \\
\hline Radiation & $3.49 * 10^{-5}$ & $8.5 * 10^{-5}$ & $1.78 * 10^{-5}$ \\
\hline Ozone layer depletion & $1.42 * 10^{-6}$ & $3.81 * 10^{-6}$ & $1.11 * 10^{-6}$ \\
\hline Ecotoxicity & 0.00667 & 0.0122 & 0.00251 \\
\hline Acidification/Eutrophication & 0.00548 & 0.0106 & 0.00186 \\
\hline Land use & 0.0639 & 0.126 & 0.0423 \\
\hline Minerals & 0.00138 & 0.00446 & 0.00083 \\
\hline Fossil fuels & 0.00138 & 0.0967 & 0.0293 \\
\hline Environmental Index 99 (EI 99) & 0.157 & 0.354 & 0.0858 \\
\hline
\end{tabular}

${ }^{(*)}: 1 \mathrm{Kg} \mathrm{EtOH} \mathrm{95 \%} \mathrm{in} \mathrm{water} \mathrm{in} \mathrm{distillery}$

\subsubsection{Alternative's B Environmental Performance}

Data from field research and data from the Ecoinvent Report n.17 were used for the evaluation of the environmental impacts of this system. Where data were not available, reasonable assumptions were made in order to calculate the missing inventory data or emissions. Some indicative emissions, in terms of volume produced per unit, are presented in Table 5. The resultant value Eco-Indicator 99 of alternative A is 0.354 . The system's performance per impact category is presented in Table 4.

Table 5: Indicative emissions from the cotton stalks ethanol production system

\begin{tabular}{lll}
\hline & Value & Note \\
\hline $\mathrm{CO}_{2}$ biogenic $(\mathrm{Kg} / \mathrm{Kg}$ EtOH) & 5.93362 & Emissions to air \\
Heat waste emissions $(\mathrm{MJ} / \mathrm{kg}$ EtOH$)$ & 45,36 & Emissions to air \\
$\mathrm{CO}(\mathrm{Kg} / \mathrm{Kg}$ EtOH) & 0.000833 & Emissions to air \\
Methane biogenic $(\mathrm{Kg} / \mathrm{Kg} \mathrm{EtOH})$ & $5.1 * 10^{-5}$ & Emissions to air \\
Mineral oil $(\mathrm{Kg} / \mathrm{Kh} \mathrm{EtOH})$ & 0.000426 & Disposal \\
\hline
\end{tabular}




\subsection{Economic Performance}

The criterion used for assessing the economic performance of each alternative is the economic performance (net economic benefit) of each alternative. A measure of the economic performance is the operation cost of each production system, including costs for feedstock, labour, maintenance, insurance \& taxes, depreciations and secondary materials. The income from the excess electricity produced is also taken into account (negative cost). The income from ethanol produced is not taken into account for the economic performance evaluation since the calculation basis is $1 \mathrm{Kg} \mathrm{EtOH}$ and thus is the same for both alternatives. The operation cost of each of the alternatives is presented in Table 6. As the excess electricity generated by the cotton stalks' ethanol system is greater in relation to the corn stover ethanol system, this leads to a decreased operational cost in the former case.

Table 6: Alternatives’ operation cost

\begin{tabular}{lcc}
\hline & $\begin{array}{c}\text { Cost of EtOH from } \\
\text { corn stover production } \\
\text { system } \mathbf{(} \mathbf{\epsilon} / \mathbf{K g} \mathbf{E t O H})\end{array}$ & $\begin{array}{c}\text { Cost of EtOH from } \\
\text { cotton stalks } \\
\text { production system } \\
(\mathbf{\epsilon} / \mathbf{K g} \text { EtOH) }\end{array}$ \\
\hline Feedstock & 0.1232 & 0.1958 \\
Other variable cost (cost for & 0.0889 & 0.1415 \\
other raw and secondary & & \\
materials) & 0.0105 & 0.0168 \\
Labor & 0.0115 & 0.0183 \\
Maintenance & 0.0850 & 0.0135 \\
Insurance \& Taxes & 0.0041 & 0.0651 \\
Depreciations & -0.1312 & -0.3510 \\
Excess electricity sales & 0.1155 & 0.1000 \\
Total & & \\
\hline
\end{tabular}

\subsection{Sustainability Performance}

According to the preceding analysis, the corn stover ethanol production system is preferable from an environmental performance perspective while the cotton stalks' ethanol system is preferable from an economic perspective. AHP may be used for the purpose of selecting the best alternative based on both criteria, by aggregating the performance of each of the alternatives in terms of both criteria and thus determining an overall index $U$ for each of the alternatives. Making the best choice is then straightforward. Table 7 summarizes the performance of each alternative in terms of both criteria. These performance values are the inverse absolute values of the EI 99 index and the total operation cost, respectively (values in parentheses). This adjustment is necessary in order for the following condition to be fulfilled:

Alternative $A$ is preferable than $B$ iff $x_{A j}>x_{B j}, j=1,2\left(x_{A j}\right.$ denotes the performance of alternative $A$ in respect to criterion $\mathrm{j}$ )

Table 7: Alternatives' performance on environmental an economic criteria

\begin{tabular}{lll}
\hline Alternative & $\begin{array}{l}\text { Environmental criterion } \\
\text { (EI 99) }\end{array}$ & $\begin{array}{l}\text { Economic } \\
\text { (operation cost) }\end{array}$ \\
\hline $\begin{array}{l}\text { EtOH from corn stover } \\
\text { (alternative A) }\end{array}$ & $\mathrm{X}_{\mathrm{A} 1: 6.37(0.157)}$ & $\mathrm{X}_{\mathrm{A} 2:} 8.66(0.1155)$ \\
$\begin{array}{l}\text { EtOH from cotton stalks } \\
\text { (alternative B) }\end{array}$ & $\mathrm{X}_{\mathrm{B} 1:}$ 2.82(0.354) & $\mathrm{X}_{\mathrm{B} 1:} 10(0.1000)$ \\
\hline
\end{tabular}


Following the AHP method, two pair-wise comparison matrices must be constructed (one for each criterion) for the determination of each alternative's score against each criterion. The values in these matrices show the decision maker's strength of preference between the two alternatives if only one criterion is taken into consideration. Based on the values presented in Table 7 the matrices are as in Table 8.

Table 8: Pairwise comparison matrices for score determination

\begin{tabular}{lcccc}
\hline & Environmental performance & \multicolumn{2}{c}{ Economic benefit } \\
\hline & ALTERNATIVE & ALTERNATIVE & ALTERNATIVE & ALTERNATIVE \\
& $\mathrm{A}$ & $\mathrm{B}$ & $\mathrm{A}$ & $\mathrm{B}$ \\
\hline ALTERNATIVE A & 1 & 5 & 1 & $1 / 3$ \\
\hline ALTERNATIVE B & $1 / 5$ & 1 & 3 & 1 \\
\hline
\end{tabular}

The calculated score values of each alternative on the selected criteria are shown in Table 9.

Table 9: Alternative scenarios’ performance values

\begin{tabular}{ccc}
\hline \multicolumn{3}{c}{ Criteria } \\
\hline Scenarios & Environmental Performance & Economic benefit \\
\hline ALTERNATIVE A & 0.83 & 0.25 \\
\hline ALTERNATIVE B & 0.17 & 0.75 \\
\hline
\end{tabular}

The pairwise comparison matrix for the determination of criteria weights is presented in Table 10. It is assumed that the environmental performance is "weekly more important" than the economic benefit criterion. This is a reasonable assumption, since biofuels come to serve environmental issues at least as much as economics considerations.

Table 10: Pairwise comparison matrix for criteria weights determination

\begin{tabular}{lcc}
\hline & Environmental performance & Economic benefit \\
\hline Environmental performance & 1 & 2 \\
\hline Economic benefit & $1 / 2$ & 1 \\
\hline
\end{tabular}

Thus the calculated weights for the environmental performance criterion $\mathrm{w}_{1}$ and for the economic benefit criterion $\mathrm{w}_{2}$ are 0.66 and 0.34 , respectively. The resulting overall performance (sustainability index) of each alternative is:

$$
\begin{aligned}
& \mathrm{U}_{\mathrm{A}}=0.66 * 0.83+0.34 * 0.25=0.6328 \\
& \mathrm{U}_{\mathrm{B}}=0.66 * 0.17+0.34 * 0.75=0.3672 .
\end{aligned}
$$

Thus alternative A must be chosen.

\section{Discussion and Conclusions}

In the present study the sustainability of two ethanol production systems was evaluated. The systems chosen will be located in Greece and use corn stover (alternative A) or cotton stalks (alternative B) as a raw material. The technology used (introduced by NREL, USA) includes prehydrolysis of raw material, simultaneous saccharification and co-fermentation process, and product, solids and water recovery stages. In addition, power is generated which is used for covering systems' needs and the excess is sold in the grid. For the sustainability evaluation, the environmental and economic performances of the alternatives were determined. It has been shown that ethanol made of corn stover has a better environmental performance than ethanol made of the cotton stalks. This is mainly due to the former's higher process production yield (in the plant) and to higher raw material yield (in the field). On the other hand, the cotton stalks ethanol system has a better economic performance than the corn stover 
one, due to the bigger excess electricity produced by the former, which is sold to the grid, providing more income. The Analytic Hierarchy Process method was used in order to aggregate the environmental and economic performances of each of the alternatives into an overall (sustainability) index. The analysis has shown that, conditioned to the assumptions made, the corn stover ethanol system is preferable. In the study no uncertainty analysis was performed. It is worthy noting that:

- Ethanol production systems from lignocellulosic materials are a promising technology which is getting more mature nowadays. In Greece there exists adequate biomass potential for the development of such systems.

- The environmental performance of both corn stover and cotton stalks ethanol systems is generally good but it is worse in comparison to ethanol produced from wood.

- The cotton stalks ethanol system has a poorer environmental performance (especially regarding the land use impact category) in relation with the corn stover one, because of its low production yield in ethanol (as a consequence of cotton stalks' low concentration in cellulose) and its low raw material production yield in cotton fields.

Further research in the area of this study must cover:

- uncertainty issues in order for the critical values for a confident decision making process to be determined

- the way the plant's production capacity affects the sustainability of the system

- the exact determination of the chemical composition of Greek agricultural residues.

\section{References}

[1] Petrou E.C.; Pappis C. P. Biofuels: A Survey on Pros and Cons. Energy Fuels, 2009, 23 (2), 1055-1066.

[2] P. Sassner, M. Galbe, G. Zacchi. Techno-economic evaluation of bioethanol production from three different lignocellulosic materials. Biomass and Bioenergy, Vol 32, issue 5, May 2008, 422-430

[3] H von Blottnitz M. A Curan. A review of assessments conducted on bio-ethanol as a transportation fuel from a net energy, greenhouse gas, and environmental life cycle perspective. Journal of Cleaner Production, Volume 15, Issue 7, 2007, 607-619

[4] http://www.biolyfe.eu

[5] http://www.nile-bioethanol.org

[6] Winston W. Operations research. Application and Algorithms. Duxbury Press. Belmond, California. 1994.

[7] Aden A.; Ruth M.; Ibsen K.; Jechura J.; Neeves K.; Sheehan J.; Wallace B.; Montague L.; Slayton A.; Lukas J. Lignocellulosic Biomass to Ethanol Process Design and Economics Utilizing Co-Current Dilute Acid Prehydrolysis and Enzymatic Hydrolysis for Corn Stover. NREL, 2002.

[8] Silverstein RA; Chen Y; Sharma-Shivappa RR; Boyette MD; Osborne J. A comparison of chemical pretreatment methods for improving saccharification of cotton stalks. Bioresource Technol. 2007; 98:3000-3011.

[9] Jungbluth N.; Chuadacoff M.; Dauriat A.; Dinkel F.; Doka G.; Faist Emmenegger M.; Gnansounou A.; Shleiss K.; Spielmann M.; Stettler C.; Sutter J. 2007: Life Cycle Inventories for Bioenergy. Ecoinvent report No 17. Swiss Centre for Life Cycle Inventories. Dubendorf, $\mathrm{CH}$.

[10]http://www.ecoinvent.org/database 